\title{
コイルばねの平行圧縮に伴う横たわみ問題*
}

\author{
久 島 士 郎*1, 神 足 勝 英*2 \\ 松 田 真一郎*3, 水 野 正 夫*4
}

\section{Lateral Deflection of Coiled Springs Caused by Parallel Compression}

\author{
Shiroh HISAJIMA, Katsuhide KOHTARI, \\ Shinichiroh MATSUDA, and Masao MIZUNO
}

\begin{abstract}
Instability theories of compression coiled springs were established some decades ago. According to these theories, when a slender coiled spring is gradually compressed, it suddenly generates a lateral deflection at the critical load. However, actual springs generate a lateral deflection gradually. When a coiled spring is compressed under condition that it is in a tube or a guided rod is inserted in it, the coiled spring may touch the wall of the tube or the rod as a consequence of lateral deflection. In this paper, compression tests were carried out for more than 200 coiled springs and lateral deflections were measured. We obtained the result that the direction and quantity of lateral deflection depends largely on the angle between the top and bottom tip-contact points of a coiled spring.
\end{abstract}

Key Words: Machine Element, Coiled Spring, Parallel Compression, Buckling, Lateral Deflection, Tip-Contact Point, Experimental Study

\section{1. 緒言}

細長いコイルばねは，軸方向に圧縮荷重を加えてい くと，ある荷重に達すると，突然横方向にたわみを生 ずるという，いわゆる座屈現象を起こすことが知られ ている。この座屈を生じる荷重については, 古くから 研究が行われている(1)(2). しかしながら，実際に用いら れている座巻を有するコイルばねは平行圧縮すると， 圧縮開始と同時に横たわみが生じ始め，その荷重が座 阊荷重以下であってもある程度の横たわみを生じる。

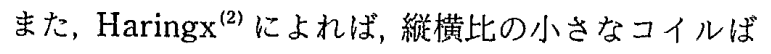
ねは座届を生じないといわれているが、これらのばね もある程度の横たわみを生じる(3).この横たわみが, コイルばねが円管内で用いられたり，コイルば权の中 にガイド棒を通して用いられたりする際にこれらと摩 擦を生じる原因となっており，摩耗や破損を引き起こ すこともある(4).そこで本研究では，座巻を有するコ

\footnotetext{
* 昭和 62 年 4 月 3 日 第 64 期通常総会講演会において讙演 原傐受付 昭和 61 年 8 月 26 日.

*1 正員, 夢応坟塾大学大学院（画223 神宗川県獚浜市港北区日 吉 $3-14-1$ ).

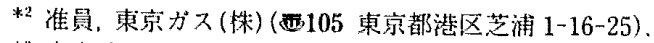

*:3 穈応義秏大学大学院.

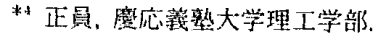

イルばねを平行圧縮した際の横たわみに関しての基礎 的な知見を得るために、コイルばねの圧縮実験を行っ た.その結果, 平行圧縮に伴うコイルばねの横たわみ 量とその方向は, Tip-Contact Pointのなす角度に大 きく依存していることがわかった，本研究の意義は， 従来あまり議論されてはいないが，事故等の原因とな る横たわみに注目したことであり，また座巻を有する コイルばねを実験対象にしたので，この結果が実用に 供せられることである。

\section{2. 実 験 方 法}

$2 \cdot 1$ 実験装置 座巻を有するコイルばねを平行 圧縮すると，図 1 のように横たわみを生じる。この時

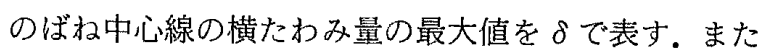
座巻部とばね有効部の接触点を, Tip-Contact Point (T. C. P.) と呼び, 上部 T. C. P.と下部 T. C. P.のな す角度（右巻のば权では図 3 のように測る）を，T.C. P.のなす角度 $\phi$ と呼ぶ。本研究を行うために, 図 2 に 示す実験装置を製作した。両端固定の端末条件を満足 させるために, 図10ように, ば权端部固定治具を用 い，横たわみ量が增大しても，座面が平行状態を保つ ようにした。また，実験は非平行状態や偏心状態が生 じないよう留意して行われ，万能試験機を用いて圧縮 
を行った。この装䈯な用いての計测に関して，次のよ うな仮定を設けた。

(a) コイルばれの压縮に伴うその中心線のたわみ 曲線は，一平面内にあるとみなす。

（b）コイルば权の変形は，両端から等烓数にある 点に関して対称であるものとする。

（c）圧縮に伴うコイル平均径の増加は, 無視でき るものとする。

横たわみの測定方法を図 3 に示す。コイルばねが横 たわみを生じると，これに接している 2 枚の板 $\mathrm{P}_{1}, \mathrm{P}_{2}$ が回転軸 $\mathrm{O}_{1}, \mathrm{O}_{2}$ のまわりを回転する. 板の回転軸より $b_{1}, b_{2}$ の距離の点にダイヤルゲージを板に直角に当て, 周方向の変位 $\delta_{1}, \delta_{2}$ を検出する.この变位より $\mathrm{P}_{1}, \mathrm{P}_{2}$ の回転角度を求め，これより横たわみ量およびその方 向を求める。このため，2枚の板は常に変形曲線の凸 側でコイルばねに接していなければならない。また， 凸側に、コイル両端から等巻数の点がない場合につい ては, 本実験装置では, 実際の横たわみ量よりも若干 小さめの計測值が得られることになる。図 3 に示すよ うに記号を定めると，ばね中心線の $x$ 方向および $y$ 方向の移動量 $\delta_{x}, \delta_{y}$ はそれぞれ式(1)，(2), 横たわ みの方向 $\omega$ は式 $(3)$ で与えられる.なお $\omega$ は, T. C. P.のなす角度 $\phi$ の二等分線を基準に, 反時計回りに測 る.

$$
\begin{aligned}
& \delta_{x}=\frac{-1}{\tan \theta_{1}+\tan \theta_{2}} \\
& \times\left\{R_{o} \sqrt{\tan ^{2} \theta_{\mathrm{l}}+1}+R_{o} \sqrt{\tan ^{2} \theta_{2}+1}-a \tan \theta_{2}\right\} \\
& -a / 2 \\
& \delta_{y}=\frac{-1}{\tan \theta_{1}+\tan \theta_{2}} \\
& \times\left\{\tan \theta_{1} \cdot R_{o} \sqrt{\tan ^{2} \theta_{2}+1}+\tan \theta_{2} \cdot R_{o} \sqrt{\tan ^{2} \theta_{1}+1}\right. \\
& \left.-a \tan \theta_{1} \cdot \tan \theta_{2}\right\}
\end{aligned}
$$

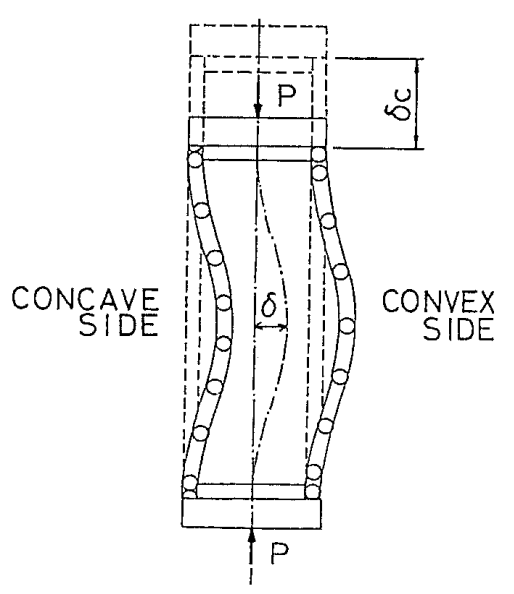

図1コイルばねの横たわみ

$$
\begin{aligned}
& \omega=\tan ^{-1}\left(\delta_{y} / \delta_{x}\right)+\pi / 2 \\
& \theta_{1}=\theta+\tan ^{-1}\left(\delta_{1} / b_{1}\right) \cdots \\
& \theta_{2}=\theta+\tan ^{-1}\left(\delta_{2} / b_{2}\right) \cdots \\
& \theta=\sin ^{-1}\left(2 R_{o} / a\right)
\end{aligned}
$$

ここで，R $R_{0}$ は,コイルば权の外半径，aは，回転軸 間の距離である. 本実験では, $R_{o}=22.5 \mathrm{~mm}, a=400$ mmである。

$2 \cdot 2$ 供試コイルばね 本実験で用いたコイルば 权の仕様を，以下に示す。

$\begin{array}{ll}\text { 線径 } & d: 5 \mathrm{~mm} \\ \text { コイル平均直径 } & D: 40 \mathrm{~mm} \\ \text { 材質 } & : S W P B \\ \text { ピッチ角 } & \alpha: 3.0^{\circ} \sim 11.9^{\circ} \\ \text { 巻方向 } & : \text { 右巻 } \\ \text { 自由高さ } & H: \text { 縦横比が } 3 \sim 7 \text { になるう } \\ & \text { た } \\ \text { 座巻 } & : \text { 両端 } 1 \text { 巻ずつ } \\ & \text { クローズドエンド（研削） } \\ & \text { 先端厚さ } d / 4 \\ \text { 外側面の傾き } & : \text { JIS B } 2707 \text { 級 }\end{array}$

(1) DEFLECTION TRANSDUCER

(2) DIAL GAGE (3) LOADCELL

(4) PLATE (5) ROTATION AXIS

(6) JIG (7) STRAIN METER

(8) A/D CONVERTER

(9) PERSONAL COMPUTER

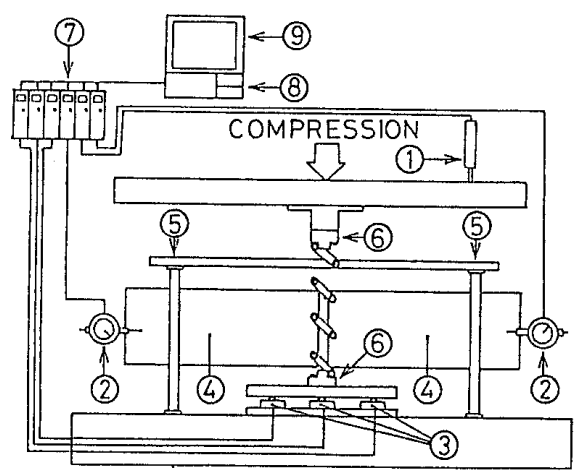

図 2 実験装置の概略図

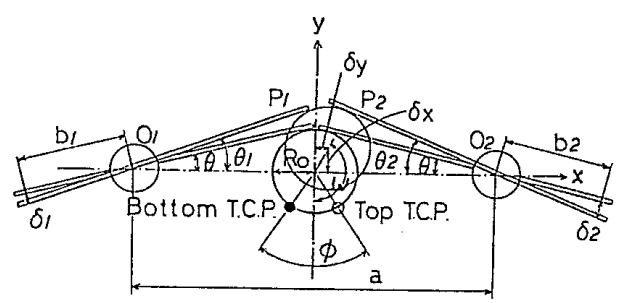

図 3 横たわみの測定方法 


\section{3. 実験結果および考密}

図 4 に,コイルばねを軸方向に $\delta_{c}$ 圧縮したときの 横たわみ量 $\delta$ を示す.これらのばねは，T.C.P.のなす 角度とピッチ角をそれぞれほほ等しくし，縦横比のみ を異なるように製作してある。これより，圧縮につれ て横たわみが増大していくばねと，圧縮につれて横た わみ量が増大した後に, 減少していくばねがあること がわかる.この傾向の分岐点は，縦横比が 5 と 5.5 と の間にあることがわかる。この結果は, Haringx ${ }^{(2)} の$ 理論による, 両端固定の端末条件では, 縦横比 5.24 以 下のコイルばねは座屈を生じないということと相通じ るところがある。

図 5 に，自由高さの $20 \%$ 軸方向圧縮量を与えた ときの，T.C. P.のなす角度 $\phi_{0}$ と，横たわみが生じる 方向 $\omega$ との関係を示す.

これより，T.C. P.のなす角度 $\phi_{0}$ が $0^{\circ}$ から $260^{\circ}$ 付 近までのばねの場合には， $\omega は 180^{\circ}$ ，すなわち横たわ みは巻数の少ない方向に生じ， $\phi_{0}$ が $260^{\circ}$ 付近から $360^{\circ}$ では， $\omega$ は $0^{\circ}\left(360^{\circ}\right)$ ，すなわち巻数の多い方向に たわむことがわかる．これは，T．．．P.のなす角度が $260^{\circ}$ 付近を境として, 横たわみの生じる方向が異なる ことを示している，仮定 $(\mathrm{b})$ によれば，たわむ方向は T.C.P.のなす角度の二等分線上 $\left(0^{\circ} ， 180^{\circ}\right)$ になるは

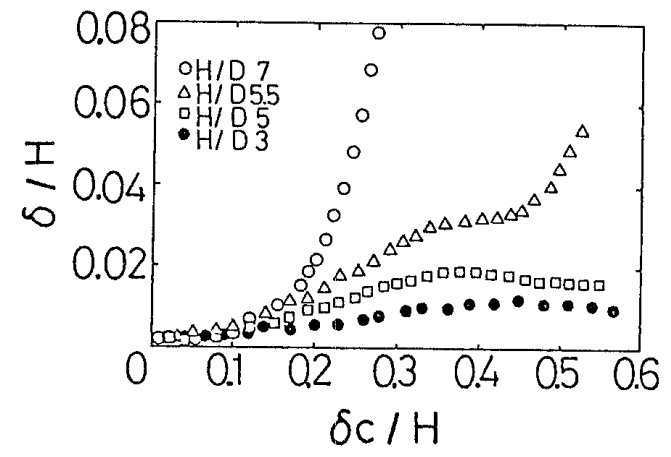

図 4 軸方向圧縮量と横たわみ量との関係

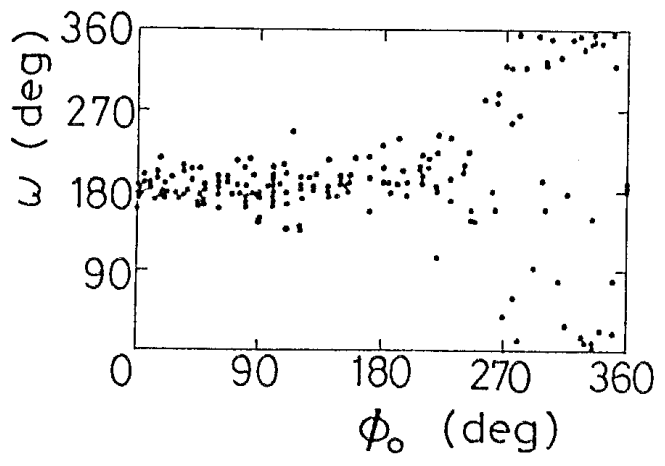

図 5 T. C.P.のなす角度と横たわみの方向との関係
ずである.実際のばねでは, T.C.P.から等ピッチに到 るまでの不等ピッチ部分の形状が上端部，下端部で微 妙に異なるので，圧縮により T. C. P.が移動すると， T.C.P.のなす角度の二等分線の方向が若干ずれる.そ のためデータのばらつきが生ずると考えられる。

図 6 に, 縦横比 6 のばねについて, 自由高さの $20 \%$ の軸方向圧縮を与えたときの，T.C. P.のなす角度 $\phi_{o}$ と圧縮による T. C. P.のなす角度の減少量 $-\Delta \phi$ との 関係を示す。これらのばねは高さを等しくし，T.C.P. のなす角度のみを変化させてある。

コイルばねを圧縮していくとばね素線同士の間隔 が小さくなっていくので, T. C. P.は有効巻数を減じ る方向に移動する.よって, T. C.P.のなす角度は小さ

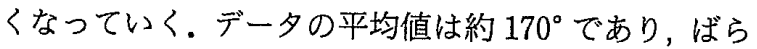
つきが， $\phi_{o}$ とあまり相関のないことより，20\%圧縮 では，横たわみは，ばね端部付近での変形にはあまり 影響をあたえていないと考えられる。

図 7 に, 自由高さの $20 \%$ 軸方向圧縮量を与えた ときの，T.C.P.のなす角度 $\phi_{o}$ と，横たわみ量 $\delta$ との 関係を示す。これらのばねは，高さを等しくし，T. C. P.のなす角度のみを変化させてある。

これより，T.C. P.のなす角度 $\phi_{o}$ が， $80^{\circ}$ 付近のば ねが最も大きな横たわみを生じ， $\phi_{o}$ が, $260^{\circ}$ 付近の ばねが最も小さな横たわみを生じ， $\delta は \phi_{o}$ に関して

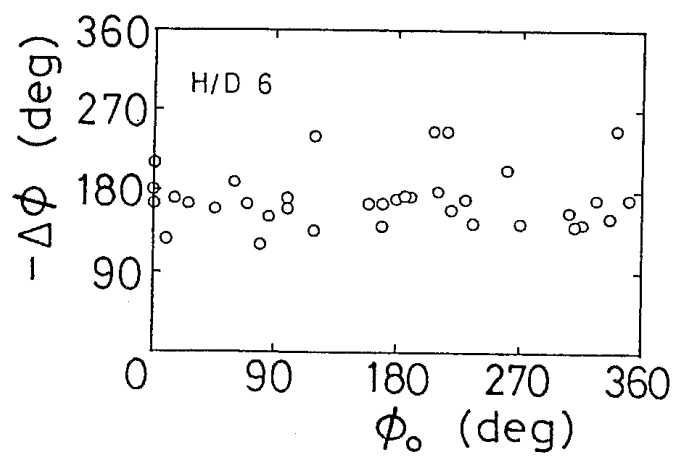

図 6 T.C.P.のなす角度と T. C.P.の移動との関係

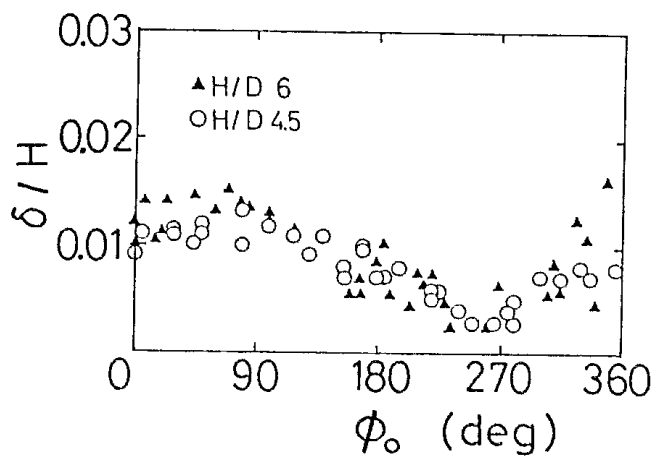

図 7 T. C. P.のなす角度と横たすみ量との関俰 


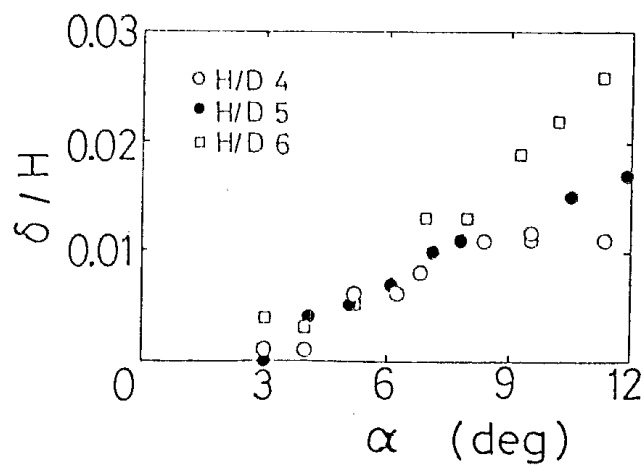

図 8 ピッチ角と横たわみ量との関係

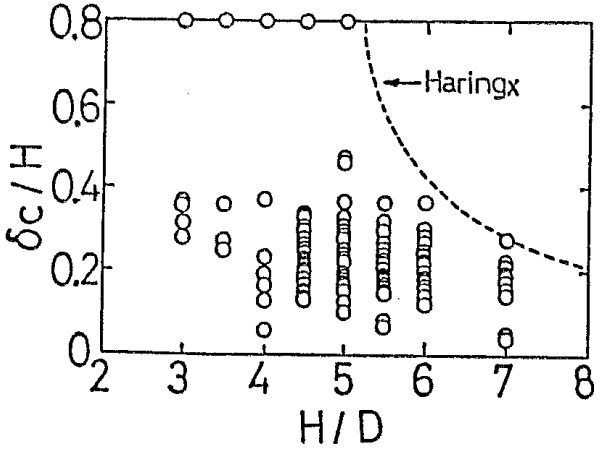

図 9 緹横比と軸方向圧縮量との関係

が知られており ${ }^{(6)(7)}$, 荷重の偏心量は, コイルばねの 巻数と縱横比の関数であるとされている( ${ }^{(8)}$.これらの ことと，今まで述べてきた結果を合せ考えると，本研 究は, 座巻による偏心荷重の作用を実験的に明らかに したといえる。

\section{4. 結言}

（1）コイルば权を圧縮すると，座屈するばねは， 座屈荷重以下の荷重でも，また座屈しないばねも，相 当量の横たわみを生じる(図 4, 図 9).

（2）コイルばね自由高さの $20 \%$ の軸方向圧縮量 では,

（i）コイルばねは，その T. C. P.のなす角度が約 $260^{\circ}$ 以下では，巻数の少ない方向にたわみ，約 $260^{\circ}$ 以上では，巻数の多い方向にたわむ（図 5 ).

（ii）その T. C. P.のなす角度が約 $80^{\circ}$ であるコイ ルばねが最も横たわみ量が大きく，約 $260^{\circ}$ であるコ イルばねが最も横たわみ量が小さい（図 7).

（iii） 圧縮され移動したT. C. P.のなす角度が $90^{\circ}$ であるとさに最も横たわみが小さい(図 6，図 7)。

（iv）ピッチ角が大きいほど，横たわみ量は大きい (図 8 ).

終わりに, 本研究用のコイルばねの製作に協力いた だいた，(株)日東発条 尾上芳充氏に梁く感謝する。

\section{文献}

(1) Hurlbrink, E., VDI Band 54, Nr4, (1910), 133.

(2) Haringx, J. A., Philips research reports, 3(1948), 401.

(3) Huhnen, J., Wire Issue 94, (1968), 73.

(4) Leech, W. J., RE-TR-68, (1971-11) (AD-739914).

(5) JIS B 2704 圧縮・引張コイルば齐設計基準.

(6) Keysor, H. C., Trans. ASME, (1940-5), 319

(7) Kuhn, R., Wire Issue 112, (1971), 51.

（8）下関・ほか 3 名, 機論, 45-396, C(昭 54), 901.

コイルばねを平行圧縮すると，その荷重の作用線は コイルばねの中心軸を通らずに，偏心荷重となること 